34 (6) : 415 427, 1984

\title{
血球の反応と型合成酵素からみた $\mathrm{A}$ 型亜型に関する研究
}

\author{
中島たみ子 \\ 群馬大学医学部法医学教室 (主任 : 古川 研教授)
}

（昭和59年 7 月26日 受付）

\section{緒言袞}

$\mathrm{A}$ 型の弱い覀型には， $\mathrm{A}_{\mathrm{int}}, \mathrm{A}_{2}, \mathrm{~A}_{3}$ などがあり, 更に弱い変異型には $\mathrm{A}_{\text {bantu }}, \mathrm{A}_{\mathrm{x}}, \mathrm{A}_{\mathrm{m}}, \mathrm{A}_{\mathrm{end}}, \mathrm{A}_{\mathrm{finn}}, \mathrm{A}_{\mathrm{e} 1}$ などが報告されている1).これらは, 血球表面の $\mathrm{A}$ 抗 原の決定基である $\alpha-(1 \rightarrow 3)$ 結合の $N$-acetyl-D -galactosaminyl 基の数が少ないことは確かである が，これが結合している糖鎖構造の全貌は末だ明ら かではない2). 亜型血球は抗 $\mathrm{A}$ ヒト血清, O型ヒト血 清中の抗 A + B血清に対する反応の強さや, Dolichos biflorus の抗 $\mathrm{A}_{1}$ レクチンとの反応の有無及び

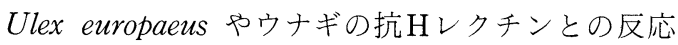
の強さによって分類されている。また, 唾液中の A 型や $\mathrm{H}$ 物質の分泌の程度やその性状によって, 赤血 球系のみの型抗原の亜型と分泌液を含めた带型に分 けられる。

$\mathrm{A}$ 型及び $\mathrm{B}$ 型遺伝子の直接の産物はそれぞれの決 定基の糖を $\mathrm{H}$ 抗原基に転移させる糖転移酵素であ る3)。A 酵素は $\alpha$-N-acetyl-D-galactosaminyl transferase で, 血清(4) 7) 及び血球膜 ${ }^{4) 8)}$ の他にヒト

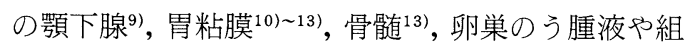
織(4) 及び母乳中15) などから存在が証明されている。 これらのA酵素のアッセイには，H活性オリゴ糖を 受容体として UDP- $\left[{ }^{14} \mathrm{C}\right]-N$-acetylgalactosamine (UDP- $\left[{ }^{14} \mathrm{C}\right]-$ GalNAc) の存在下でオリゴ糖への $\left[{ }^{14} \mathrm{C}\right]-$ GalNAc の取り込みを放射活性で測定する方 法と, O型血球を受容体としてUDP-GalNAc の存 在下でA型血球への変換を血清学的に測定する方法 とがある。 $\mathrm{A}_{1}$ や $\mathrm{A}_{2}$ 型のヒ卜血清中の $\mathrm{A}$ 酵素活性 は,オリゴ糖への GalNAcの取り込みでみると, $\mathrm{A}_{2}$ では $\mathrm{A}_{1}$ 型の $1 / 5$ から $1 / 10$ であり ${ }^{6)}$, 金属イオン要求 性, 至適 $\mathrm{pH}$, 受容体や糖又クレオチドに対する $\mathrm{Km}$ 值 ${ }^{16)}$, 等電点 ${ }^{17)}$ などで性状が異なり, 酵素に量的及 び質的な違いがあることが示唆されている．O血球 ひ型変換でも, $\mathrm{A}_{1}$ 型に対し $\mathrm{A}_{2}$ 型の血清では $\mathrm{A}$ 変換
血球の抗 $\mathrm{A}$ 被凝集性は非常に弱いことが報告されて いる ${ }^{18)}$.

ここでは，A型亜型の検査に新たに日本産の Falcata japonica (ヤブマメ) レクチン19121) を加え, 血清学的に亜型の分類を明確にし, それぞれの亜型 血清中の A酵素を血球の型変換で調べる方法を確立 したので報告する。

\section{材料及び方法}

1. 血球及び唾液

血液は ACD 液または Alsever 液中で保存した。 $\mathrm{A}$ 型严型血球は当教室での検査から得られたもの と, 赤十字血液センターから分与されたものを用い た。酵素処理血球は，パパイン (Difco社) 及びフィ シン (和光純薬) は $1 \%$ 生理的食塩水溶液を, ノイラ ミニダーゼ処理は, Vibrio cholerae のノイラミニ ダーゼ (Calbiochem 社, $1 \mathrm{IU} / \mathrm{ml}$ ) を生食で10倍に 希釈したものを用い，いずれも遠心沈殿血球に等量 加え, $37^{\circ} \mathrm{C} て ゙ 30$ 分加温処理後, 血球を生食で 1 回洗 浄した。凝集反応には $2 \%$ 血球浮遊液を用いた。唾 液は, 沸とう水中で 30 分加熱後, 遠心上清を用いた。

2. 抗血清及び植物凝集素

抗 $\mathrm{H}$ 血清は, ニワトリのヒト $\mathrm{O}$ 型血球免疫血清と, ウサギの II 型血清を用いた。抗 $\mathrm{A}$ 標準血清は，B型 のヒト血清及び Ortho 社のものを用い, 抗 $\mathrm{A}$ ヒト血 球免疫ウサギ血清は東京標準血清のものと自家製の ものを用いた。抗 $A_{1}$ 血清は， $A_{2} B$ 型のヒト血清を 用いた。抗 $\mathrm{B}$ 標準血清は $\mathrm{A}$ 型ヒト血清と Ortho 社の

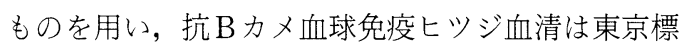
準血清を用いた。抗 $\mathrm{A}+\mathrm{B}$ 血清は，O型のヒト血清 と Ortho 社のものを用いた。抗 Cad 血清は, ニワ トリに $\mathrm{Cad}(+)$ 血球を免疫し,得られた血清を $\mathrm{Cad}$ (一) 血球で吸収したものを用いた。

Dolichos biflorus (DBA) 及び Falcata japonica (FJA) レクチンは以下の方法で部分精製した。それ 
ぞれの種子 $10 \mathrm{~g}$ をコーヒーミルで粉研後, $100 \mathrm{ml}$ の $0.01 \mathrm{M}$ リン酸カリ緩衝液 $(\mathrm{pH} 7.4)$ を加え, $37^{\circ} \mathrm{C} て ゙$ 2 時間攪汼抽出後, 遠心上清の硫安 $80 \%$ 飽和沈殿分 画を緩衝液に溶解し, Sephacryl S-200 ゲルロ過の $\mathrm{A}$ 血球凝集分画を濃縮して強さを調整した。Ara chis hypogaea (ピーナッツ) (AHA) レクチンは, 生のピーナッツ豆を10倍量の $0.01 \mathrm{M} リ ン$ 酸緩衝液 （pH 7.4）で抽出し，遠心上清に硫安を $80 \%$ 飽和に なるまで加え，Sephadex G-100によるゲルロ過分 画を濃縮したものを用いた。

血清の抗体免疫グロブリン分画は DEAE-cellulose クロマトグラフィーで行った22223).

3. 血球及び唾液の凝集阻止試験

遠心沈殿血球及び唾液を倍数希釈し，凝集素価 4 倍の抗血清またはレクチンを等量加え，2 時間室温 に放置後血球は遠心上清をとり，それぞれ対応する 血球との反応で凝集阻止価を判定した.

4. 型合成酵素活性の測定

酵素源には, $-20^{\circ} \mathrm{C}$ に凍結保存したヒト血清を用 いた。糖ヌクレオチドは, ガルサーブ $\mathrm{AB}$ (三光純 薬) の $1.6 \mathrm{mM}$ の UDP- $N$-acetylgalactosamine (UDP-GalNAc) と UDP-galactose (UDP-Gal) を 用いた。測定にはガルサーブ AB 及び Cartron ${ }^{18)} ら$ の変法を用いた。応標準液は, 血清 $50 \mu 1$ にDPGalNAc 及び UDP-Gal $20 \mu 1,0.1 \mathrm{M} \mathrm{Mncl}_{2} \cdot 4 \mathrm{H}_{2} \mathrm{O}$

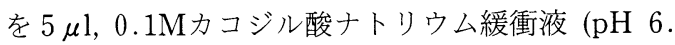
0)または，0.1Mトリス-塩酸緩衝液 $(\mathrm{pH} 7.2) 35 \mu 1$ と $\mathrm{O}$ 型洗浄血球 $10 \mu 1$ を加え, 総量 $120 \mu 1$ を $37^{\circ} \mathrm{C} て ゙$ 14〜18時間まで攪挥しながら作用させた，反応終了 後, 血球を生食で 3 回洗浄して $2 \%$ 血球浮遊液とし て抗血清やレクチンに対する被凝集価を測定した。

\section{成績}

I 、 A 型の亜型の反応

1) $A_{\text {int }}$ 型の家族例 (Tak. 家)
発端者は25才の健康な女性で, 血球の被凝集価は, $\mathrm{A}_{1}$ 型に対する凝集素価128倍の抗 $\mathrm{A}$ ヒト血清に64倍 で1管弱く反応し, 凝集素価128倍の抗 B ヒ卜血清に 1 管強く256倍であった(表 1 )。 $\mathrm{A}_{1}$ 血球に対する凝 集素価を64倍に調整した DBA と FJA との反応は それぞれ 1 倍及び16倍であった。血清中には抗A及 び抗B凝集素は認められなかった。唾液は，H，A， $\mathrm{B}$ 型物質を正常の $\mathrm{A}_{1} \mathrm{~B}$ 型と同程度に分泌していた。 家族調査では（図 1), 父 $(I-2)$ は $A_{1} B$ で，母 (II-3) は AB 型であるが, 血球は抗 $\mathrm{A}$ ヒト血清, DBA, FJA に対し発端者（II-1）と同じように弱 く, 抗 $\mathrm{B}$ ヒト血清との反応は正常であった。血清中 には抗 $\mathrm{A}$ 及び抗B凝集素は認められなかった。母の 姉 $(I-1)$ は A型で, 血球は抗 A ヒト血清及び FJA に対しIIー1 と同じ被凝集価を示したが，DBA と は 4 倍でやや強かった。血清中には抗B凝集素のみ

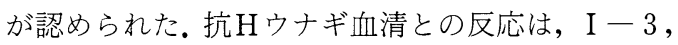
II-1は 1 倍で弱く, I - 1 は 128 倍で $\mathrm{A}_{2}$ 血球より もやや弱かったＩ－1，I-3 及びII-1の血球 は，抗 $\mathrm{Cad}$ 二ワトリ免疫血清とは反応しない $\mathrm{Cad}$ (一)であり, 前述の DBA との反応はA抗原との反 応である。 その他の血液型抗原の強さや遺伝関係に 異常は認められなかった。血球の $\mathrm{A}$ 抗原との強さの 差を, 抗 $\mathrm{A}$ ヒト血清との凝集阻止試験（表 2 ） と, 血球量を $1 / 5$ から等量まで変えて吸収し， 2 時間後の 遠心上清の反応を比較する吸収試験（表 3 ）で調心゙ た. I - 1, I - 3, II- 1 はいずれも凝集阻止価 は $\mathrm{A}_{1}$ と $\mathrm{A}_{2}$ の中間にあり, 吸収試験では等量加え ても凝集素価128倍の抗 $\mathrm{A}$ 上卜血清を吸収すること は出来ず， $A_{2}$ と同じ性状を示した。従って，これら の血球の $\mathrm{A}$ 抗原は量的には $\mathrm{A}_{1}$ 型と $\mathrm{A}_{2}$ 型の中間に あり，血清学的には $\mathrm{A}_{2}$ 型と共通の亜型の性状を 持っていることがわかった。

唾液中の血液型物質は表 4 のように $\mathrm{I}-1$ は $\mathrm{H}$ と $\mathrm{A}$ 型物質の正常の分泌型であった。 I - 3 は， B 型

表 1 Tak. 家系員血球の被凝集性

\begin{tabular}{|c|c|c|c|c|c|}
\hline \multirow{2}{*}{ 家系員番号 } & & 被 & 凝 & 価 & \\
\hline & 抗 $A$ ヒ & $\mathrm{D} B \Lambda$ & $\mathrm{F} \mathrm{J} \mathrm{A}$ & 抗 $B$ ヒト & 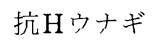 \\
\hline $\mathrm{I}-1$ & 64 & 4 & 16 & 0 & 128 \\
\hline $\mathrm{I}-2$ & 128 & 64 & 64 & 128 & 1 \\
\hline $\mathrm{I}-3$ & 64 & 1 & 16 & 256 & 1 \\
\hline II -1 & 64 & 1 & 16 & 256 & 1 \\
\hline
\end{tabular}


表 2 Tak. 家系員血球の凝集阻止試験

\begin{tabular}{|c|c|c|c|c|c|c|c|c|}
\hline \multirow{2}{*}{ 血 } & \multirow{2}{*}{ 球 } & \multicolumn{2}{|c|}{ 凝 } & 集 & 阻 & 止 & \multicolumn{2}{|l|}{ 価 } \\
\hline & & $\mathrm{A}_{1}$ & I -1 & $A_{1} B$ & $\mathrm{~A}_{2} \mathrm{~B}$ & $I-3$ & II - 1 & $\mathrm{~A}_{3} \mathrm{~B}$ \\
\hline 抗 $A$ ヒト & $\mathrm{A}_{1}$ & 512 & 64 & 256 & 8 & 64 & 32 & 2 \\
\hline
\end{tabular}

表 3 Tak. 家系員血球による抗A ト血清の吸収試験

\begin{tabular}{rrrrrrrrr}
\hline 吸収血球 & \multicolumn{7}{c}{ 吸収後の抗 $\mathrm{A} ヒ$ ト血清の $\mathrm{A}_{1}$ 型血球に対する凝集素価 } \\
\cline { 2 - 9 }$\mu \mathrm{l}$ & $\mathrm{A}_{1}$ & $\mathrm{~A}_{2}$ & $\mathrm{I}-1$ & $\mathrm{~A}_{1} \mathrm{~B}$ & $\mathrm{~A}_{2} \mathrm{~B}$ & $\mathrm{I}-3$ & $\mathrm{II}-1$ & $\mathrm{~A}_{3} \mathrm{~B}$ \\
\hline 0 & 128 & 128 & 128 & 128 & 128 & 128 & 128 & 128 \\
20 & 8 & 16 & 32 & 16 & 64 & 32 & 32 & 64 \\
40 & 2 & 16 & 16 & 4 & 32 & 16 & 16 & 64 \\
60 & 1 & 16 & 16 & 4 & 16 & 8 & 4 & 64 \\
80 & 0 & 16 & 8 & 2 & 16 & 4 & 4 & 64 \\
100 & 0 & 16 & 8 & 1 & 16 & 4 & 4 & 32 \\
\hline
\end{tabular}

I

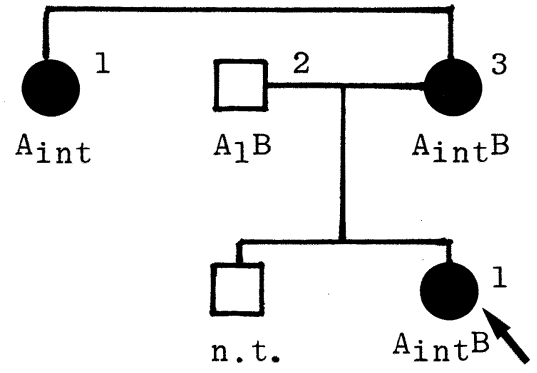

図 $1 \mathrm{~A}_{\mathrm{int}}$ 型の家系図 (Tak. 家) 矢印は発端者. n. t. は未検査

物質は正常の分泌型であるが, A 型物質は弱い分泌 型で, 抗 $\mathrm{A}$ 及び抗 $\mathrm{A}_{1}$ ヒト血清と $\mathrm{A}_{1}$ 型血球との反 応阻止力ょりも, 抗 $A$ ヒト血清と $A_{2}$ 型血球との反
応阻止力が強く, $\mathrm{A}_{2}$ 型と同じ亜型の性状をもってい た.これらの家系員のA抗原の強さとその血清学的 性状は, $\mathrm{A}_{1}$ 型と $\mathrm{A}_{2}$ 型のいずれにも一致しないいわ ゆる intermediate と考えられるので, 発端者（II - 1) とその母親 $(\mathrm{I}-3)$ を $\mathrm{A}_{\mathrm{int}} \mathrm{B}$, 母の姉 $(\mathrm{I}-1)$ を $\mathrm{A}_{\text {int }}$ 型とすることにした。

2）その他のA型覀型

$\mathrm{A}$ 型の亜型には $\mathrm{A}_{\mathrm{int}}$ に次いで強さの順に $\mathrm{A}_{2}, \mathrm{~A}_{3}$ などがあり, 血球の型は抗 $\mathrm{A}$ ヒト血清に対する被凝 集価, $\mathrm{A}_{2}$ 以下の血球が $\mathrm{DBA}$ と反応しないこと及

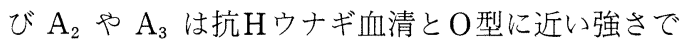
反応することなどから判定されている。ここでは FJA をも加え, 部分精製した高力価のレクチンを用 いて $\mathrm{A}_{1}, \mathrm{~A}_{2}, \mathrm{~A}_{3}$ 型血球に対する反応性を比較した (表 5 )。 $A_{1}$ 型血球に対する標準凝集素価256倍の

表 4 Tak. 家系員唾液中の型物質

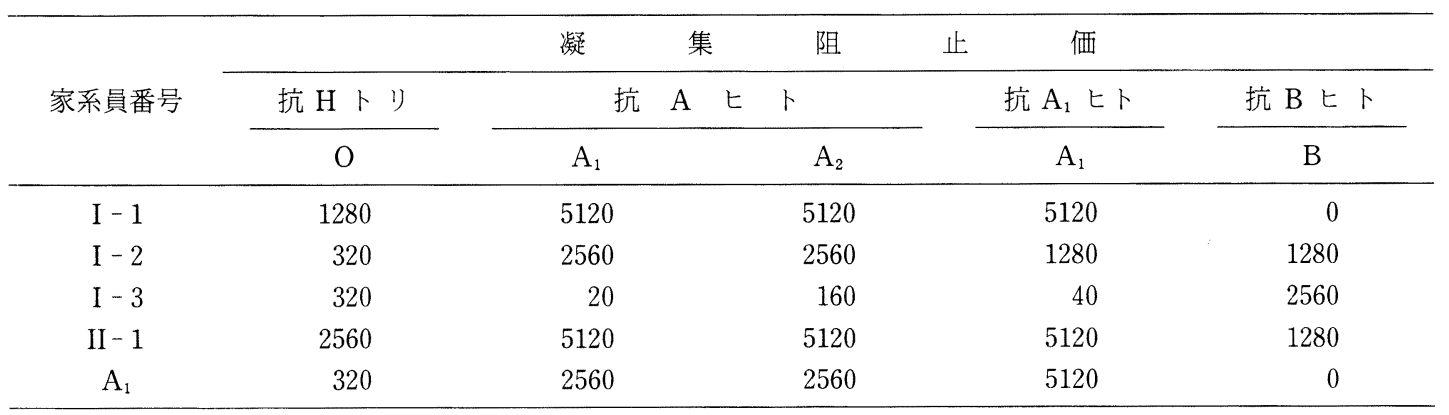


表 $5 \mathrm{~A}_{1}, \mathrm{~A}_{2}, \mathrm{~A}_{3}$ 型血球の FJA 及び DBA に対する 反応性

\begin{tabular}{|c|c|c|c|}
\hline \multirow{2}{*}{ 球 } & 凝 & 素 & 価 \\
\hline & 抗 $A ヒ 卜$ & FJA & DBA \\
\hline$A_{1}$ & 256 & 512 & 256 \\
\hline $\mathrm{A}_{2}$ & 32 & 64 & 2 \\
\hline $\mathrm{A}_{3}$ & 4 & 0 & 0 \\
\hline
\end{tabular}

抗 $\mathrm{A}$ ヒト血清に対する被凝集価がそれぞれ32倍及び 4 倍の $\mathrm{A}_{2}$ 及び $\mathrm{A}_{3}$ 血球は， $\mathrm{A}_{1}$ 型血球に対する標準 凝集素価512倍の FJA に対し, $\mathrm{A}_{2}$ 血球の被凝集価 は64倍であるが $\mathrm{A}_{3}$ 血球とは反応が認められない. $\mathrm{A}_{1}$ 血球に対する標準凝集素価256倍の DBA は, $\mathrm{A}_{2}$ 血球の被凝集価は 2 倍で, $\mathrm{A}_{3}$ 血球とは反応が認めら れない. そこで, FJA が $\mathrm{A}_{2}$ と反応し, $\mathrm{DBA}$ が $\mathrm{A}_{2}$ と反応しない強さとして，それぞれ $\mathrm{A}_{1}$ 及び $\mathrm{A}_{1} \mathrm{~B}$ 血 球に対する標準凝集素価を64倍に調整し，A型亜型 血球の反応の違いを比較した (表 6 )。 $A_{1}$ 血球との 反応が256倍, $A_{1} B$ 血球と128倍の抗 $A$ 上卜血清を用 いると, $\mathrm{A}_{2}$ 及び $\mathrm{A}_{2} \mathrm{~B}$ とされている一群の血球の被 凝集価は16-64倍の範囲にあり, $\mathrm{A}_{1}$ 及び $\mathrm{A}_{1} \mathrm{~B}$ 血球 に比べ倍数希䣋で $\mathrm{A}_{2}$ では $2 \sim 4$ 管, $\mathrm{A}_{2} \mathrm{~B}$ では 1 〜 管弱い. $\mathrm{A}_{3}$ 及び $\mathrm{A}_{3} \mathrm{~B}$ とされている群の被凝集 価は 1 ～倍の範囲に入り, 強さにややばらつきが あり，凝集する血球と凝集しない血球とが混在する いわゆる mixed-field agglutination を示す例と, 示さない例とがあった。標準凝集素価64倍の DBA は, $A_{2}, A_{2} B$ 及び $A_{3}, A_{3} B$ 型血球とは反応しないの
で, $\mathrm{A}_{1}$ と $\mathrm{A}_{2}$ 以下の亜型との判定に適している. 標 準凝集素価64倍の FJA には $\mathrm{A}_{2}$ 血球も反応し, $\mathrm{A}_{2}$ 血球群は 2 16倍, $\mathrm{A}_{2} \mathrm{~B}$ 血球群は 1 ～16倍で強さに ばらつきがみられた。しかし， $\mathrm{A}_{3}$ 及び $\mathrm{A}_{3} \mathrm{~B}$ 血球群 は反応しないので $\mathrm{A}_{2}$ と $\mathrm{A}_{3}$ 型とを反応の有無で判 定できる。また，O型血球と1024倍で反応する抗 $\mathrm{H}$ ウナギ血清を用いると，A型の亜型ではO 型に近い 被凝集性を示すので， $A_{1}$ と区別できる。

3） $\mathrm{Cad}$ 及び $\mathrm{Tn}$ 型血球との区別

FJA 及び DBA は GalNAc を非環元末端に持つ 抗原と反応するので， $\mathrm{O}$ 型や $\mathrm{B}$ 型でも $\mathrm{Sd}(\mathrm{a}+)$ や $\mathrm{Cad}(+)$ 及び $\mathrm{Tn}$ 型血球を凝集する (表 7 )。従っ て，A型の場合これらのレクチンと反応するものに ついて抗 $\mathrm{Cad}$ ニワトリ免疫血清による $\mathrm{Cad}(+)$ 型 の特異反応, $\mathrm{AB}$ 型血清及び $\mathrm{AHA}$ による T及び $\mathrm{Tn}$ 型の反応をみておく必要がある。そこで，ここで用 いたA型の亜型について Cad, Tn, Tの反応を調べ てみたが，陽性のものは見出されなかった。

表 7 A 型以外の各型血球の F J A 及び DBA に対 する反応性

\begin{tabular}{|c|c|c|c|c|c|}
\hline \multirow{3}{*}{ 血 } & \multirow{3}{*}{ 球 } & \multicolumn{2}{|c|}{ 凝 } & \multicolumn{2}{|l|}{ 素 } \\
\hline & & \multicolumn{2}{|c|}{ FJA } & \multicolumn{2}{|c|}{ DBA } \\
\hline & & saline & papain & saline & papain \\
\hline \multicolumn{3}{|c|}{$\mathrm{O} \operatorname{Cad}(+++) 64$} & 1024 & 2048 & 8192 \\
\hline $\mathrm{O}$ & & 0 & 1024 & 0 & 1 \\
\hline $\mathrm{O}$ & & 0 & 128 & 0 & 0 \\
\hline $\mathrm{B}$ & & 512 & 1024 & 64 & 0 \\
\hline $\mathrm{O}^{\prime}$ & & 64 & & 0 & \\
\hline
\end{tabular}

表 6 A 型亚型血球の各抗体に対する被凝集性

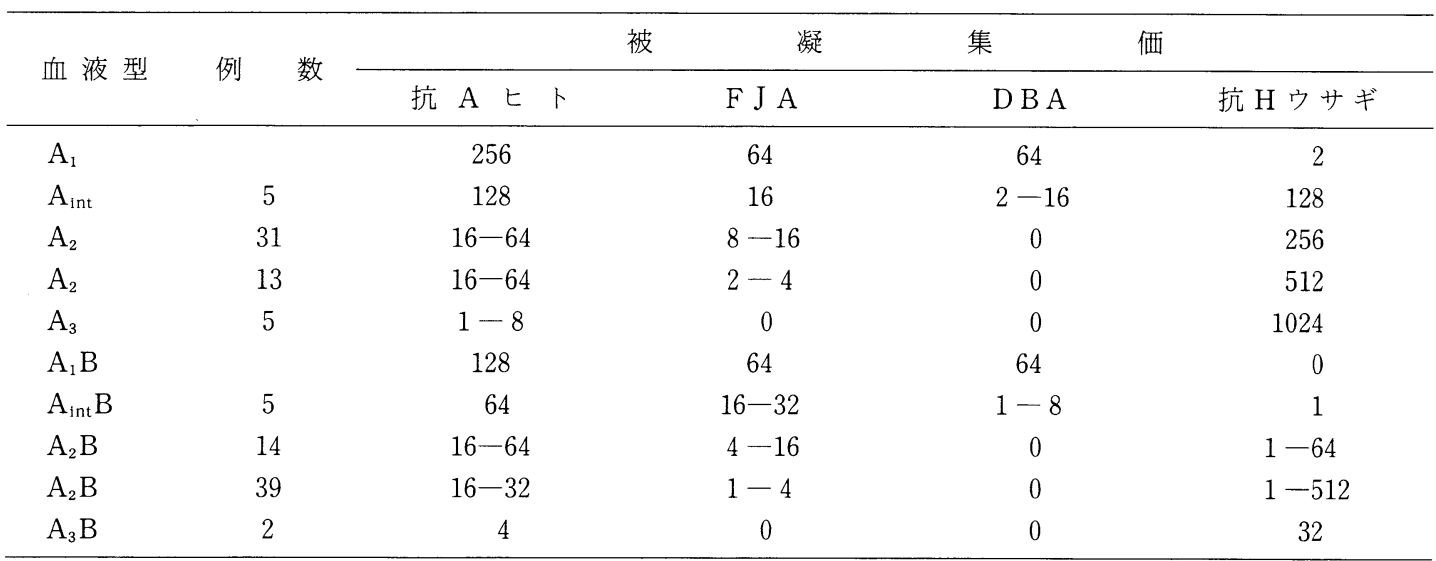


II. 血球の型変換による血清中の $\mathrm{A}$ 合成酵素

O型血球を受容体として, UDP-GalNAc の存在 下でA酵素 $(\alpha-N$-acetyl-D-galactosaminyltransferase) を作用させると, $\mathrm{O}$ 型の $\mathrm{H}$ 活性基のタイプ 2 糖鎖の非環元末端の Gal に GalNAc が $\boldsymbol{\alpha}-(1 \rightarrow 3)$ で転移してA型抗原活性基がつくられる。その過程 は次のようである。
告をもとに UDP-GalNAc, $\mathrm{MnCl}_{2}$, カコジル酸ナト リウム緩衝液, 血清及び血球量について比べ, 標準 反応液を表 8 のように決めた. UDP-GalNAc, $\mathrm{MnCl}_{2}$ 及び血清量をそれぞれ 2 倍にしても変換血 球の $\mathrm{A}$ 型活性は変わらなかった。 反応液の酵素活性 化金属イオン, 至適 $\mathrm{pH}$, 反応時間の検討結果の詳細 は後述する。また, 血球汇対して反応液を繰り返し とり換えて作用させると, 変換血球の A 型活性は 2

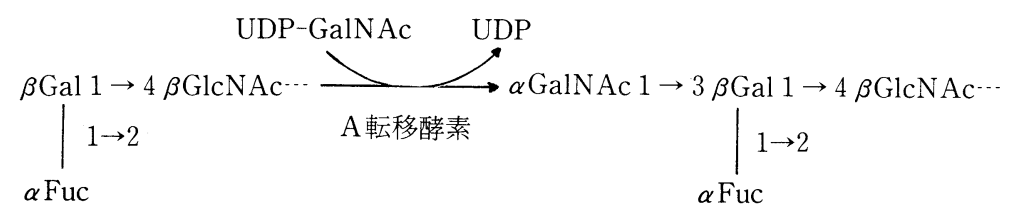

( $\mathrm{O}$ 型血球の $\mathrm{H}$ 抗原末端基)

1） $A_{1}$ 型血清を用いた反応液の組成の比較 亜型血清を酵素源として O 型血球から $\mathrm{A}$ 型血球へ の型変換による A 合成酵素活性の測定を, これまで

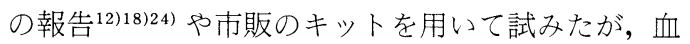
球は抗A血清によって凝集する程強まらない。そこ で， $A_{1}$ 血清を用いて型変換を強めるための反応条 件を検討した。先づ, 反応液の組成をこれまでの報

表 8 A醅素によるO血球から $\mathrm{A}$ 血球への型変換のた めの標準反応液の組成

\begin{tabular}{lc}
\hline UDP-GalNAc & $32.5 \mathrm{nmol}$ \\
$\mathrm{MnCl}_{2}$ & $0.5 \mu \mathrm{mol}$ \\
緩衝液 $\mathrm{pH} 6.0^{*}$ & $35.0 \mu \mathrm{l}$ \\
$\mathrm{A}_{1}$ 型血清 & $50.0 \mu \mathrm{1}$ \\
O型血球 & $10.0 \mu \mathrm{l}$ \\
\hline
\end{tabular}

*カコジル酸ナトリウム緩衝液。反応液の最終 $\mathrm{pH}$ は アルカリ側に移動するので直接測定する必要があ

る. $37^{\circ} \mathrm{C} て ゙ ，$ 最高 18 時間作用させた。
( $\mathrm{A}$ 型血球の $\mathrm{A}$ 型抗原末端基)

倍までは上昇したが，A型と同程度の強さになるに は至らなかった。

受容体の $\mathrm{O}$ 型血球を未処理の生血球とタンパク分 解酵素処理血球で比較すると，表 9 のように生血球 に比べて酵素処理血球の型変換では, 抗 $\mathrm{A}$ ヒト血清 に対する被凝集価が倍数希釈法で 8 倍強まった。ま た抗 Aウサギ免疫血清では, 酵素処理血球は生血球 よりも被凝集価が32倍強まり, 正常の $\mathrm{A}_{1}$ パパイン 処理血球と同じ強さになった。 $\mathrm{O}$ 型生血球による型 変換では, 変換血球は抗 $\mathrm{A}$ 上卜血清とは反応するが DBA とは反応しないので， $A_{2}$ 型くらいの強さであ るが, 酵素処理した血球による型変換では DBA と 反応し, 被凝集価は $\mathrm{A}_{\mathrm{int}}$ の強さであった。型変換血 球は，抗Hウナギ血清に対する被凝集性はやや低下 していた。

2) $\mathrm{A}$ 型两型血清中の $\mathrm{A}$ 酵素

$\mathrm{A}_{1}$ と $\mathrm{A}_{2}$ の酵素の至適 $\mathrm{pH}$ をこれまでの報告8) 16)25/36) と後述の至適 $\mathrm{pH}$ の検討結果から, 表 8 の標

表 9 酵素処理血球を受容体に用いた型変換

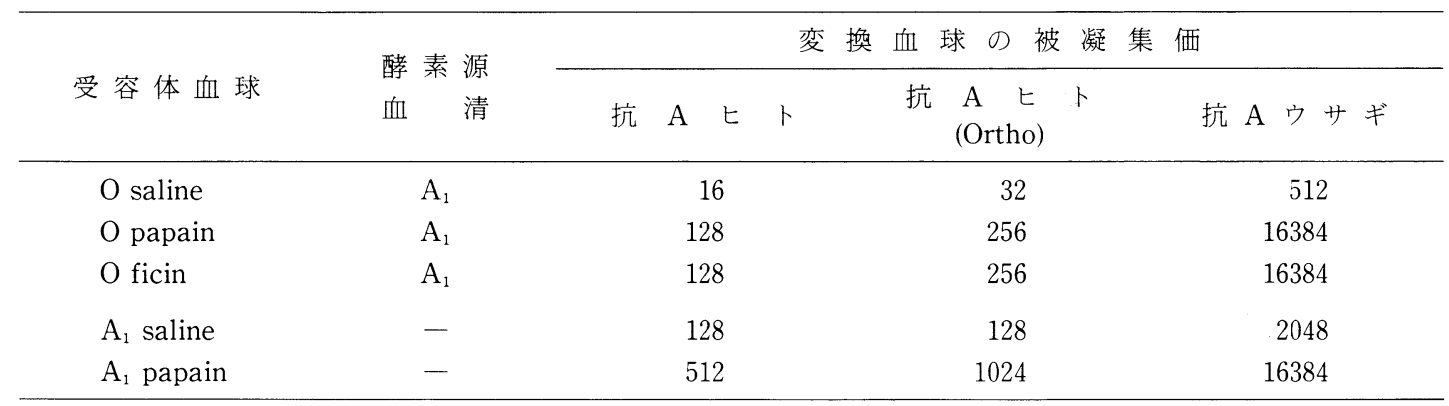


準反応液の緩衝液をトリ又塩酸緩衝液 $\mathrm{pH} 7.2$ に変 え, A 型亜型血清中の A 合成酵素活性を調べた。後 述のように, 反応液の $\mathrm{pH}$ は $\mathrm{A}_{2}$ 型酵素の至適 $\mathrm{pH}$ 7.6に移動している.受容体としてはO型パパイン処 理血球を用い, 変換血球の判定には抗 A ヒト標準血 清及び抗Aウサギ免疫血清を用いた。結果は表10に 示すようで，ここで調べた図 1 の $\mathrm{A}_{\mathrm{int}}$ の家系員と $\mathrm{A}_{2}, \mathrm{~A}_{2} \mathrm{~B}, \mathrm{~A}_{3} \mathrm{~B}$ では, 赤血球の抗 $\mathrm{A}$ 被凝集価と平行
して血清中の $\mathrm{A}$ 合成酵素活性も弱い。そして, $A_{1}$ と $\mathrm{A}_{2}, \mathrm{~A}_{2}$ と $\mathrm{A}_{3}$ の差は明瞭であるが, $\mathrm{A}_{\mathrm{int}}$ の個体差の 下限と $\mathrm{A}_{2}$ の上限は重複していた。 $\mathrm{A}_{\text {int }} \mathrm{B}$ 型血清に よる変換血球のみが， DBA と弱く反応し，O型が $\mathrm{A}_{\mathrm{int}}$ 型に変換しているが，他は $\mathrm{A}_{2}$ 以下の強さで あった。また， $\mathrm{A}$ と $\mathrm{AB}$ とでは酵素活性は $\mathrm{A}_{\mathrm{int}} \mathrm{B}>$ $\mathrm{A}_{\text {int }}, \mathrm{A}_{2} \mathrm{~B}>\mathrm{A}_{2}, \mathrm{~A}_{3} \mathrm{~B}>\mathrm{A}_{3}$ で，B因子をもつている 方が $\mathrm{A}$ 合成酵素活性が高かった。

表10 型変換血球の被凝集価からみた $\mathrm{A}$ 型亜型血清中の $\mathrm{A}$ 酵素活性

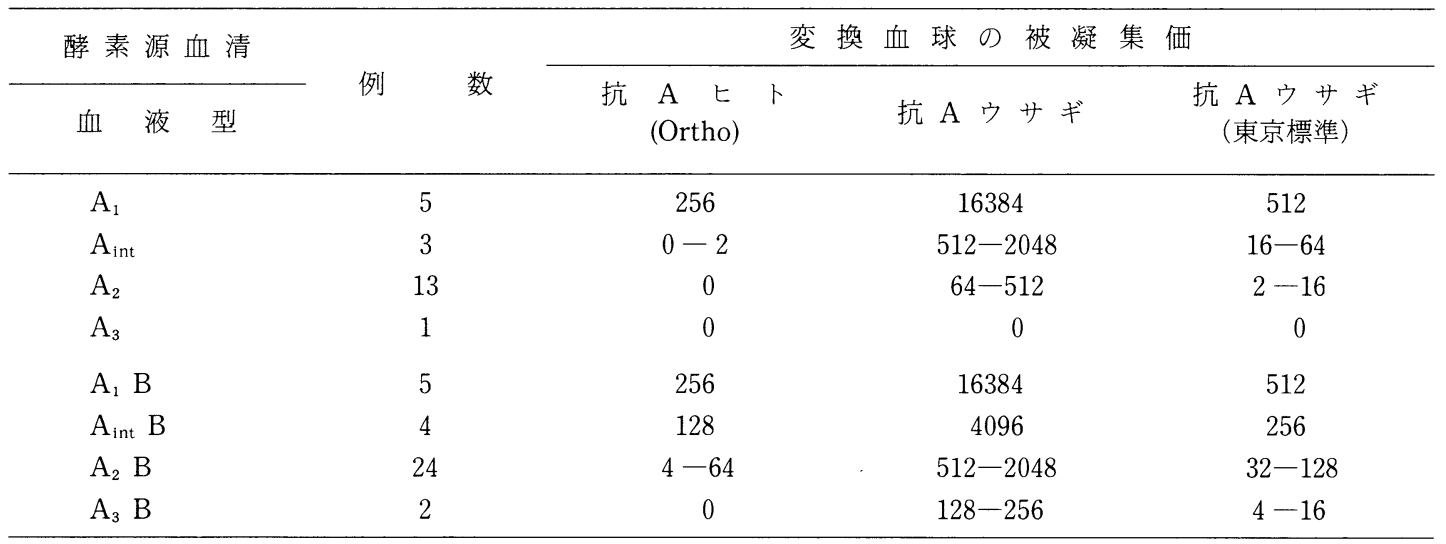

表11 酵素処理を型変換の前後で行った場合の比較

\begin{tabular}{|c|c|c|c|c|c|c|c|}
\hline \multirow{2}{*}{ 酵素源血清 } & \multirow{2}{*}{ 受容体血 球 } & \multirow{2}{*}{\multicolumn{2}{|c|}{ 変 換 血 球 }} & \multicolumn{4}{|c|}{ 変 換 血 球 の 被 凝 集 価 } \\
\hline & & & & 抗 & $A \quad t$ & ト & 抗 $\mathrm{A}$ ウサギ \\
\hline \multirow[t]{3}{*}{$\mathrm{A}_{1}$} & O saline & saline & & & 32 & & 512 \\
\hline & & papain & & & 128 & & 4096 \\
\hline & O papain & & & & 256 & & 16384 \\
\hline \multirow[t]{3}{*}{$\mathrm{A}_{2}$} & O saline & saline & & & 0 & & 0 \\
\hline & & papain & & & 0 & & 128 \\
\hline & O papain & & & & 0 & & 512 \\
\hline
\end{tabular}

表12 抗A ヒト血清及び抗 Aウサギ免疫血清の免疫グロブリン分画

\begin{tabular}{|c|c|c|c|c|c|c|c|c|c|}
\hline \multirow{3}{*}{ 分 } & \multirow{3}{*}{ 画 } & \multicolumn{3}{|c|}{ 凝 } & 集 & \multicolumn{2}{|l|}{ 素 } & \multicolumn{2}{|c|}{ 価 } \\
\hline & & 抗 & A & 七 & ト & 抗 & A & ウ & サ \\
\hline & & \multicolumn{2}{|c|}{ saline } & \multicolumn{2}{|r|}{ papain } & \multicolumn{2}{|c|}{ saline } & \multicolumn{2}{|r|}{ papain } \\
\hline 分 & 前 & \multicolumn{2}{|c|}{128} & \multicolumn{2}{|r|}{1024} & \multicolumn{2}{|c|}{2048} & \multicolumn{2}{|r|}{16384} \\
\hline \multicolumn{2}{|c|}{ F 1 (IgG) } & \multicolumn{2}{|c|}{2} & \multicolumn{2}{|r|}{64} & \multicolumn{2}{|c|}{512} & \multicolumn{2}{|r|}{4096} \\
\hline \multicolumn{2}{|c|}{ F $2(\operatorname{Ig} A, \operatorname{Ig} G)$} & \multicolumn{2}{|c|}{16} & \multicolumn{2}{|r|}{64} & \multicolumn{2}{|c|}{512} & \multicolumn{2}{|r|}{4096} \\
\hline \multicolumn{2}{|c|}{ F $3(\operatorname{IgM})$} & \multicolumn{2}{|c|}{32} & \multicolumn{2}{|r|}{256} & \multicolumn{2}{|c|}{64} & \multicolumn{2}{|r|}{512} \\
\hline
\end{tabular}


$\mathrm{O}$ 生血球の型変換では, 変換血球をパパイン処理 すると, $\mathrm{A}_{1}$ 血清を酵素源とした場合, 抗 $\mathrm{A}$ ヒト血清 に対して 4 倍, 抗Aウサギ免疫血清に対して128倍被 凝集価が強まる(表11)。 $\mathrm{A}_{2}$ 血清を酵素源とすると， $\mathrm{O}$ 生血球の型変換では, 血球は抗 $\mathrm{A}$ 血清と反応する に至らないが，これをパパイン処理すると抗 $\mathrm{A} ヒ ト$

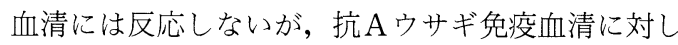
て強い凝集が認められた。しかし，いずれの場合も O型パパイン処理血球による型変換の方が, 変換血 球の抗 $\mathrm{A}$ 被凝集価が高く, 生血球よりもパパイン処 理血球への GalNAc の転移が多いことがわかった。

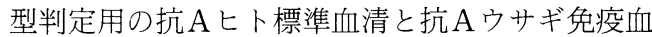
清との反応性の違いを明らかにする為に，それぞれ の血清の免疫グロブリンを DEAE-cellulose カラム クロマトグラフィーで分画した(表12).この方法で は，カラムに結合しないF 1 分画に $\operatorname{IgG}$ が， 0.125 $\mathrm{M}$ の $\mathrm{NaCl}$ で溶出する分面 $\mathrm{F} 2$ に $\operatorname{IgA}$ と $\operatorname{IgG}$ の一 部が, $0.25 \mathrm{M}$ の $\mathrm{NaCl}$ で溶出する分画 $\mathrm{F} 3$ には IgM と僅かの IgG, IgA が含まれている22)23). 抗A凝集 活性はいずれの分画にもあるが，抗 $A$ ヒト血清は IgM 分画に，抗Aウサギ免疫血清では IgG 分画に それぞれ最も強い凝集素活性が認められた。

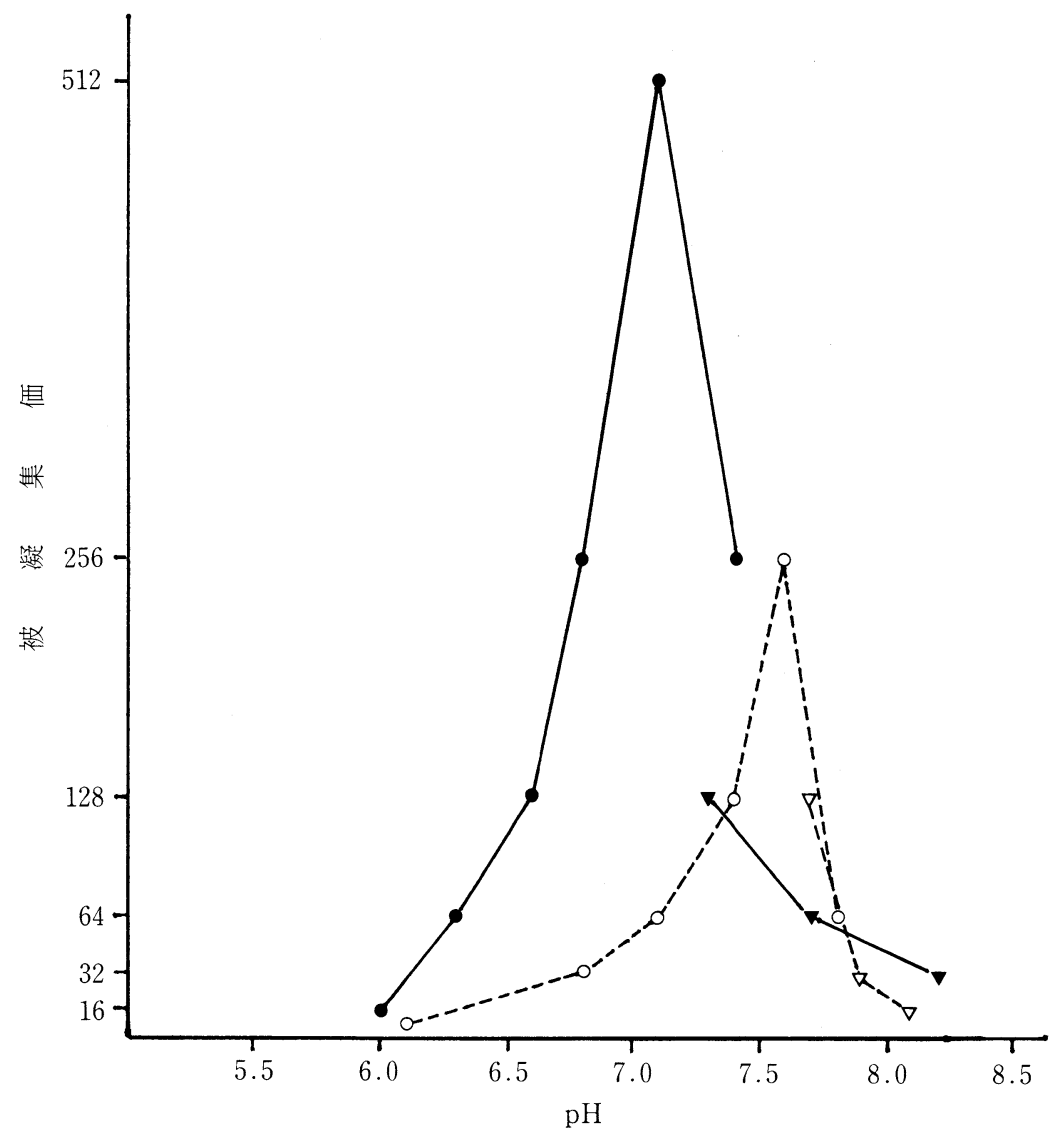

図 2 A 酵素活性の $\mathrm{pH}$ の影響

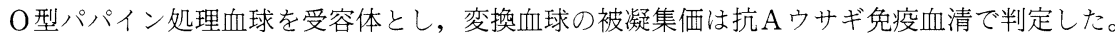
$37^{\circ} \mathrm{C}$ で14時間作用。

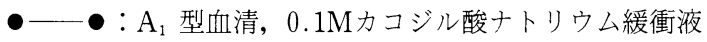

$\boldsymbol{\nabla}$ 一 $: \mathrm{A}_{1}$ 型血清, $0.1 \mathrm{M}$ 卜リス-塩酸緩衝液

$\bigcirc \cdots \cdots \cap: \mathrm{A}_{2}$ 型血清, $0.1 \mathrm{M}$ カコジル酸ナトリウム緩衝液

$\nabla \cdots-\cdots: \mathrm{A}_{2}$ 型血清, $0.1 \mathrm{M}$ 卜リス-塩酸緩衝液 
3） $\mathrm{A}_{1}$ 及び $\mathrm{A}_{2}$ 型血清中の $\mathrm{A}$ 酵素の性状

a) 金属イオンの影響

前述の標準反応液から金属イオンを除くと，O型 血球から $\mathrm{A}$ 型血球への型変換を凝集反応で証明する ことは出来ない.変換血球の抗 $\mathrm{A}$ 被凝集価の強さか らみると，二価の金属イオンでは $\mathrm{A}_{1}$ 型血清中の酵 素は $\mathrm{Mn}^{++}, \mathrm{Co}^{++}$次いで $\mathrm{Cd}^{++}$の順で, $\mathrm{Mg}^{++}$や $\mathrm{Zn}^{++}$でも酵素の活性化を証明出来るが, $\mathrm{Ba}^{++}$, $\mathrm{Ca}^{++}, \mathrm{Fe}^{++}, \mathrm{Ni}^{++}$では酵素の活性化を認めることは 出来なかった。 $\mathrm{A}_{2}$ 型血清でも $\mathrm{Mn}^{++}$がよく, $\mathrm{Cd}^{++}$ や $\mathrm{Mg}^{++}$でも酵素の活性化を証明し得た。

b) 至適 $\mathrm{pH}$

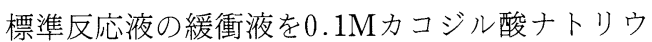
厶緩衝液 $\mathrm{pH} 5.2 \sim 7.2,0.1 \mathrm{M}$ 卜リス一塩酸緩衝液 $\mathrm{pH}$ 6.8〜8.6の間にして反応液の $\mathrm{pH}$ を測定する と, 加えた緩衝液の $\mathrm{pH}$ よりもアルカリ側に移動し ていた。これは酵素源として加えた血清の存在によ るものと考えられる。そこで, 反応液の $\mathrm{pH}$ の実測 值をもとに酵素の至適 $\mathrm{pH}$ を求めた. 図 2 のように, $\mathrm{A}$ 型変換血球の抗 $\mathrm{A}$ 被凝集価から得られた $\mathrm{A}_{1}$ 酵素 の至適 $\mathrm{pH}$ は7.1， $\mathrm{A}_{2}$ 酵素は $\mathrm{pH} 7.6$ で $\mathrm{A}_{1}$ と $\mathrm{A}_{2}$ で は異っていた。

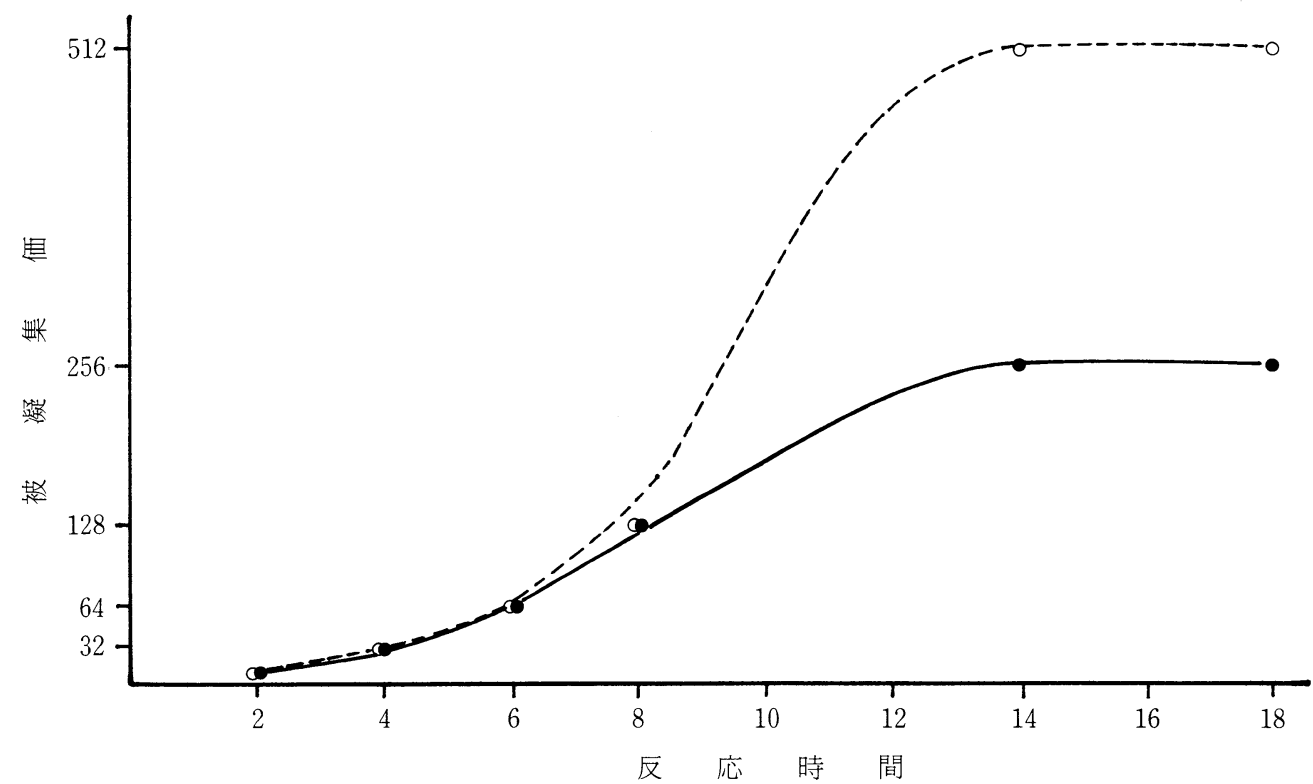

図 3 反応時間と $\mathrm{A}$ 変換血球の被凝集価

O型パパイン処理血球を受容体として作用.

-—— : $\mathrm{A}_{1}$ 型血清, 抗 $\mathrm{A}$ ヒト血清で判定.

$\bigcirc — 0: A_{2}$ 型血清, 抗 $A$ ウサギ免疫血清で判定.
III. B型血清中のA酵素活性

B型七ト血清を反応液の酵素源とし, UDP-GalNAc の存在下で反応させた. O型の生血球及びパパ イン処理血球はいずれも $\mathrm{A}_{1}$ 型血清を用いたものよ り弱いが $\mathrm{A}$ 型に変換し， B型血清中にも弱い $\mathrm{A}$ 酵素 活性が存在することが証明された。一方，A型血清 にはB酵素活性を認めることはできなかった。対照 の $\mathrm{O}$ 型血清を酵素源として加えた反応液でも $\mathrm{A}$ 型や B型への変換は認められなかった。（表13）

\section{B型血清中のB酵素}

B 型血清を酵素源としてO 型パパイン処理血球を 用いて UDP-Gal の存在下でB型への型変換をみる と, $\mathrm{O}$ 生血球よりも変換血球の被凝集価は高く, 抗 B ヒト血清で判定するよりも抗 $\mathrm{B}$ ヒツジ免疫血清の 方がより高かった。 B型の亜型血清でも, 表14に示 すように $\mathrm{A}_{1} \mathrm{~B}_{2}$ 型血清では $\mathrm{O}$ 生血球からの変換では 
表13 UDP-GalNAc の存在下における $\mathrm{A}_{1}, \mathrm{~B}, \mathrm{O}$ 血 清を用いた O血球から $\mathrm{A}$ 血球への型変換

\begin{tabular}{|c|c|c|c|}
\hline \multirow{3}{*}{$\begin{array}{l}\text { 酵素源 } \\
\text { 血 清 }\end{array}$} & \multirow{3}{*}{ 受容体血球 } & \multicolumn{2}{|c|}{ 変換血球の被凝集価 } \\
\hline & & \multirow{2}{*}{$\begin{array}{c}\text { 抗 A ヒ ト } \\
\text { (Ortho) }\end{array}$} & \multirow{2}{*}{ 抗Aウサギ } \\
\hline & & & \\
\hline \multirow[t]{2}{*}{$\mathrm{A}_{1}$} & $\mathrm{O}$ saline & 32 & 512 \\
\hline & O papain & 256 & 16384 \\
\hline \multirow[t]{2}{*}{$\mathrm{B}$} & O saline & 0 & 64 \\
\hline & O papain & 0 & 512 \\
\hline \multirow[t]{2}{*}{$\mathrm{O}$} & O saline & 0 & 0 \\
\hline & O papain & 0 & 0 \\
\hline - & $A_{1}$ saline & 128 & 2048 \\
\hline - & $A_{1}$ papain & 1024 & 16384 \\
\hline
\end{tabular}

抗 B血清に凝集しないが，Oパパイン処理血球での 変換では変換血球は抗 $\mathrm{B}$ ヒト血清と弱く, 抗 $\mathrm{B}$ ヒツ ジ免疫血清とは強く反応し, $\mathrm{A}$ 型の亜型と同様に $\mathrm{B}$ 型亜型血清中の B 酵素の存在と強さの違いを証明す ることが出来た。

\section{考察}

$\mathrm{A}$ 型の亜型の $\mathrm{A}_{2}$ や $\mathrm{A}_{3}$ は, 血球の抗 $\mathrm{A}$ 標準血清 に対する被凝集性, DBA との反応の有無, 抗Hウナ ギ血清との反応の強さで, 更に弱い変異型は抗A抗 体の吸収試験や吸着解離試験によって判定されてい る. 血球 1 個当りの表面の $A$ 抗原の密度は, $A_{1}$ で凡 そ 100 万， $\mathrm{A}_{2}$ では凡そ $1 / 4^{26) 27)}, \mathrm{A}_{3}$ では $1 / 20 \sim 1 / 30$, 変異型は 1 万以下であるとされている ${ }^{28)}$.ここで用 いた FJB は, $\mathrm{A}_{2}$ や $\mathrm{A}_{2} \mathrm{~B}$ の強さに分類される血球
群とは $\mathrm{A}_{1}$ 血球よりも弱いが反応し, $\mathrm{A}_{3}$ や $\mathrm{A}_{3} \mathrm{~B}$ の 強さの血球群とは反応しないので, $\mathrm{A}_{2}$ と $\mathrm{A}_{3}$ の型の 区別に有用なレクチンであることが証明された。ま た，抗 $\mathrm{A}$ ヒト血清の被凝集性に差のない $\mathrm{A}_{2}$ や $\mathrm{A}_{2} \mathrm{~B}$ でも, FJA では強弱の反応が認められ亜型の間に差 を認めることが出来る。

抗 $\mathrm{A}$ ヒト血清に対して $\mathrm{A}_{1}$ と $\mathrm{A}_{2}$ の中間の強さを 示す $A_{\text {int }}$ は黒人に多くみられ，抗 $A$ レタンとの反 応が $A_{2}$ に近いものと $A_{1}$ に近いものがある1).ここ で報告した Tak. 家系の 3 名の $\mathrm{A}_{\mathrm{int}}$ 及び $\mathrm{A}_{\mathrm{int}} \mathrm{B}$ は, 血球の被凝集性はいずれも直接凝集反応でみると $\mathrm{A}_{1}$ 及び $\mathrm{A}_{1} \mathrm{~B}$ に近いが, 抗 $\mathrm{A}$ ヒト血清を吸収しにく い点は $\mathrm{A}_{2}$ に似ている。唾液の $\mathrm{A}$ 型物質は $\mathrm{I}-1$ と $\mathrm{II}-1$ は $\mathrm{A}_{1}$ と同程度の分泌型で, I- 3 はA 型物 質が $\mathrm{A}_{1}$ 血球よりも $\mathrm{A}_{2}$ 血球による凝集阻止価が高 $く, \mathrm{~A}_{2}$ 型の唾液の性状に一致している ${ }^{29)}$. 血清中の $\mathrm{A}$ 酵素を $\mathrm{O}$ 型生血球を受容体とした型変換でみる と, 変換血球の被凝集価は II -1 は $\mathrm{A}_{1} \mathrm{~B}$ 型と同程度 の強さを示すが， I - 1 と I - 3 は倍数希釈でそれ ぞれ $1 / 32$ と $1 / 8$ 低い值を示し,酵素活性の強さに差が みられた。パパイン処理血球を用いて変換血球を抗 Aウサギ免疫血清で判定すると, II - 1 が I - 1 と $\mathrm{I}-3$ よりも 2 倍強いが, $\mathrm{A}_{1}$ と $\mathrm{A}_{2}$ の中間の強さで あった。このように，Tak. 家系では同じ家系内の $\mathrm{A}_{\text {int }}$ 型でもそれぞれ性状が異っていた. Yoshida ら ${ }^{30)}$ は $A_{\text {int }}$ 型の血清中のA酵素を 2'-fucosyllactose を受容体とし, GalNAc のとり込みで測定 すると, $\mathrm{A}_{1}$ や $\mathrm{A}_{2}$ とは酵素の至適 $\mathrm{pH}$, 受容体や UDP-GalNAc に対する $\mathrm{Km}$ 值が異っているので, $A_{1}, A_{2}$ 遺伝子とは別の $A_{\text {int }}$ 遺伝子の存在が考えら

表14 B覀型血清中の B 酵素による O血球の B 血球への型変換

\begin{tabular}{|c|c|c|c|c|c|c|c|}
\hline \multirow{2}{*}{$\begin{array}{c}\text { 酵素源血清 } \\
\text { 血 液 型 }\end{array}$} & \multirow[b]{2}{*}{ 受容体血球 } & \multicolumn{6}{|c|}{ 変換 血球 の被 凝 集 価 } \\
\hline & & 抗 & $\mathrm{B}$ & r & 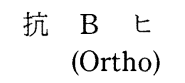 & ト & $\begin{array}{c}\text { 抗 B ヒ ツ ジ } \\
\text { (東京標準) }\end{array}$ \\
\hline \multirow[t]{2}{*}{$\mathrm{B}$} & O saline & \multicolumn{3}{|c|}{16} & \multicolumn{2}{|l|}{64} & 64 \\
\hline & $\mathrm{O}$ papain & \multicolumn{3}{|c|}{64} & \multicolumn{2}{|l|}{256} & 512 \\
\hline \multirow[t]{2}{*}{$\mathrm{B}_{\mathrm{m}}$} & O saline & \multicolumn{3}{|c|}{2} & \multicolumn{2}{|l|}{8} & 16 \\
\hline & O papain & \multicolumn{3}{|c|}{32} & \multicolumn{2}{|l|}{64} & 128 \\
\hline \multirow[t]{2}{*}{$\mathrm{A}_{1} \mathrm{~B}_{2}$} & O saline & \multicolumn{3}{|c|}{0} & \multicolumn{2}{|l|}{0} & 0 \\
\hline & O papain & \multicolumn{3}{|c|}{4} & \multicolumn{2}{|l|}{8} & 128 \\
\hline- & B saline & \multicolumn{3}{|c|}{64} & \multicolumn{2}{|l|}{128} & 128 \\
\hline- & B papain & \multicolumn{2}{|r|}{256} & & \multicolumn{2}{|l|}{512} & 1024 \\
\hline
\end{tabular}


れるとしている.

これまでの報告や市販のガルサーブ $\mathrm{AB}$ による 方法では，A型の亜型血清を酵素源とした場合，血 球の型変換を被凝集性でみることは困難である。こ こでは, 酵素処理血球の被凝集性が特に IgG 抗体に 対して強まることから, 変換血球に用いる受容体の O血球をあらかじめパパイン処理し，さらに抗体は IgG 抗体を多く含む動物免疫血清を用いることに よって, 亜型血清中の型合成酵素活性を血球の型変 換で測定することを可能にした。そして血球の蛋白 分解酵素処理で, 血球表面のシアル酸を含む糖蛋白 ペプチド鎖の一部が除かれることは，GalNAc の転 移の立体障害が除かれることにもなっている。この ことは, 生血球を受容体として反応液に加えて作用 させた後, 血球をパパイン処理したものの抗 Aウサ ギ免疫血清に対する被凝集価よりも，パパイン処理 血球を受容体として反応液を加えた型変換血球の被 凝集価の方が 4 倍高いことから証明された（表11）。

$\mathrm{A}$ 型の亜型血清中の $\mathrm{A}$ 酵素活性は, 血球抗原の被 凝集性と共に弱い. Cartron ら ${ }^{8)}$ は, $\mathrm{A}_{2}, \mathrm{~A}_{3}, \mathrm{~A}_{\mathrm{m}}$ 型 の血清中のA酵素は活性が弱く, $\mathrm{A}_{\mathrm{x}}, \mathrm{A}_{\mathrm{end}}, \mathrm{A}_{\mathrm{el}}$ では $\mathrm{A}$ 酵素が証明されないことをみている。変換血球の 被凝集価から凡その比較を行ってみると, $\mathrm{A}_{1}$ に比 べ, $\mathrm{A}_{\text {int }}$ では $1 / 8 \sim 1 / 32, \mathrm{~A}_{2}$ では $1 / 32 \sim 1 / 256$ で, $\mathrm{A}_{1}$ $\mathrm{B}$ に比べ $\mathrm{A}_{\mathrm{int}} \mathrm{B}$ では $1 / 4, \mathrm{~A}_{2} \mathrm{~B}$ では $1 / 8 \sim 1 / 32, \mathrm{~A}_{3}$ $B$ では $1 / 64 \sim 1 / 128$ 弱い. 血球の型変換でみる限り, $\mathrm{A}$ 型の亜型では $\mathrm{A}_{1}$ との比較で血球の $\mathrm{A}$ 抗原の量的 な差よりも血清中の酵素活性の強さの差の方が大き くなっている。また, $\mathrm{A}_{\mathrm{int}} \mathrm{B} や \mathrm{~A}_{2} \mathrm{~B} て ゙ は, \mathrm{~A}_{\mathrm{int}}$ や $\mathrm{A}_{2}$ に比べて $2 \sim 8$ 倍強く, $\mathrm{A}_{3}$ では型変換を抗 $\mathrm{A}$ 七 ト及びウサギ免疫血清で証明し得ないが, $\mathrm{A}_{3} \mathrm{~B}$ 血清 のA酵素は型変換で証明が可能である。 AB 型の血 清中にはA酵素，B酵素の他に両方の活性を持った 酵素分子の存在が示され， A酵素は $\mathrm{aa}, \mathrm{B}$ 酵素は bb のホモダイマーで, AB 型血清中には $\mathrm{aa}, \mathrm{bb}$ の他 にへテロダイマーの $\mathrm{ab}$ が存在するといわれてい $る^{31}$. 最近, Yoshida ら ${ }^{32)}$ は, 黒人や東洋人に $\mathrm{A}_{2}$ 型の頻度が $\mathrm{A}$ 型よりも $\mathrm{AB}$ 型に多いことを指摘し, $\mathrm{A}_{2} \mathrm{~B}$ 型とされているヒトの中には血清中に $\mathrm{A}_{1}$ 酵素 をもち, B醉素が正常よりも強い活性をもつ alypical B酵素をもつものがあり, A酵素と atypical B 酵素との競合によって A抗原の占める割合が少なく なり, $\mathrm{A}_{2} \mathrm{~B}$ の活性をもつものがあると考え， $B$ 遺伝 子は正常な $B$ 遺伝子と atypical $\mathrm{B}$ 酵素を支配する
$B^{2}$ 遺伝子に分けられるとしている.今回ここで調べ て $\mathrm{A}_{2} \mathrm{~B}$ 型と判定したものの中には， $\mathrm{A}_{1}$ 酵素と同じ 程度の強い活性をもつものは見出されなかった。

Watkins ら ${ }^{33)}$ は，B酵素が UDP-GalNAc の存 在下でH活性をもつオリゴ糖や $\mathrm{O}$ 型血球に GalNAc を転移することをみている。また，Yates ら ${ }^{34)}$ は濃縮した $\mathrm{A}_{1}$ 血清を用いて, UDP-Gal の存在下 で2'-fucosyllactose に Gal をとり込ませることが 出来ると報告している。ここでは, B 型血清を酵素 源に用いた $\mathrm{O}$ パパイン処理血球の $\mathrm{A}$ 変換血球は, $\mathrm{A}_{2}$ 酵素によるそれと同程度の強さであった。しかし， $\mathrm{A}_{1}$ 血清では UDP-Gal の存在下で $\mathrm{O}$ 血球の B 型へ の変換を証明することはできなかった。

Schachter ら ${ }^{16)}$ は, $\mathrm{A}_{1}$ と $\mathrm{A}_{2}$ の血清中のA酵素 は至適 $\mathrm{pH}$ が異なり，オリゴ糖への GalNAc のと り込みでみると, $\mathrm{A}_{1}$ では $\mathrm{pH} 5.6, \mathrm{~A}_{2}$ では $\mathrm{pH} 7$ 〜 8の間であるとし, 他では精製した $\mathrm{A}_{1}$ 酵素の至 適 $\mathrm{pH}$ は6.57), 6.5 7.0 3 (35) であるともいわれてい る.血球の型変換での至適 $\mathrm{pH}$ は $\mathrm{A}_{1}$ では7.1, $\mathrm{A}_{2}$ では $\mathrm{pH} 7.6 て ゙ ， \mathrm{~A}_{1}$ よりも $\mathrm{A}_{2}$ がアルカリ側にある ことは一致していたが, $A_{1}$ の值がややアルカリ側で あった。また，Nakajima ${ }^{36)} ら は ， A_{\text {int }}$ 型の血清中 のA酵素は，血球の型変換やオリゴ糖へのとり込み でみると， $\mathrm{A}_{1}$ 酵素活性を測定する条件 $(\mathrm{pH} 6.0)$ 上 りも $\mathrm{A}_{2}$ 酵素を測定する条件 $(\mathrm{pH} 7.0$ ～7.2) を用い いた方が高い活性が得られたこと, $\mathrm{A}_{\mathrm{int}}$ の至適 $\mathrm{pH}$ をオリゴ糖へのとり込みから求めると, $\mathrm{A}_{1}$ と $\mathrm{A}_{2}$ の 中間にあり $\mathrm{A}_{1}, \mathrm{~A}_{\mathrm{int}}, \mathrm{A}_{2}$ の $\mathrm{A}$ 合成酵素はそれぞれ性 状が異っていることを見ている。

$\mathrm{B}$ 血清中の $\mathrm{B}$ 酵素の活性は $\mathrm{B}_{\mathrm{m}}$ 型では血球は抗 $\mathrm{B}$ 標準血清とは反応せず， $\mathrm{B}_{2}$ や $\mathrm{B}_{3}$ よりも弱い変異型 であるが, 血清中の $\mathrm{B}$ 酵素は $\mathrm{A}_{1} \mathrm{~B}_{2}$ よりも強い. $\mathrm{A}_{1}$ $\mathrm{B}_{2}$ では $\mathrm{O}$ 型パパイン処理血球でのみ変換が証明で きるが， $\mathrm{B}_{\mathrm{m}}$ では $\mathrm{O}$ 生血球でも変換が証明でき，血球 の $\mathrm{B}$ 抗原の強さと䤃素の強さが亜型同士で一致しな い. Kościelak ら ${ }^{37)}$ は， $\mathrm{B}_{\mathrm{m}}$ 型の血清中のB酵素は $\mathrm{B}$ 型と同様に強く，血球膜の $\mathrm{B}$ 酵素は弱いとしてい るが, Kogure ${ }^{38)}$ は $\mathrm{B}_{\mathrm{m}}$ 型の血清中の B 酵素活性は

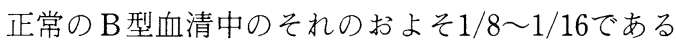
と考光られるとしている。これらのくい違いは， $\mathrm{B}_{\mathrm{m}}$ では骨髄系の酵素に異常があり, 分泌腺の酵素生成 に異常はないので, 血清中の酵素は骨䯣由来のもの と分泌腺由来の酵素の影響によるものと考えられ る. Cartron ら ${ }^{18)} も, \mathrm{~A}_{\mathrm{m}}$ 型の血清中の $\mathrm{A}$ 酵素は $\mathrm{A}_{2}$ 
に近いものであるが，ほとんどが $\mathrm{A}_{2}$ よりも強く， 血球膜8)にはA酵素がほとんど認められないことを 報告している。

\section{結 論}

1. A 型亜型血球の検査にこれまで用いられてい る抗A 標準血清, Dolichos biflorus, 抗Hレクチンの 他に, Falcata japonica を加え $\mathrm{A}_{1}, \mathrm{~A}_{\mathrm{int}}, \mathrm{A}_{2}, \mathrm{~A}_{3}$ の判 定基準を設定した。この検査法により, 同じ家系内 で血球や唾液の $\mathrm{A}$ 抗原に強さに差を持つ $\mathrm{A}_{\mathrm{int}}$ 型の 家族例を見出した。凝集素価を64倍に調製した $D$. biflorus は $\mathrm{A}_{2}$ と $\mathrm{A}_{3}$ に反応せず, F. japonica は $\mathrm{A}_{3}$ に反応しないので, これらのレクチンの使用は $\mathrm{A}_{2}$ と $\mathrm{A}_{3}$ の判定に適していることがわかった。また， $\mathrm{A}_{2}$ では F. japonica に対する反応性の強さにばら つきがみられた。

2. 受容体血球に $\mathrm{O}$ 型パパイン処理血球を, 型変 換血球の被凝集価の判定に動物免疫血清を用いて, 血球の型変換で $\mathrm{A}$ 型や $\mathrm{B}$ 型の亜型の血清中の弱い型 合成酵素を測定することを可能にした，亜型では， 血球の抗原と共に血清中の酵素活性も弱いが， $\mathrm{B}_{\mathrm{m}}$ の酵素活性は $\mathrm{B}_{2}$ よりも強かった。

B型血清を酵素源として UDP-GalNAc の存在 下で $\mathrm{O}$ 型血球が $\mathrm{A}$ 型に変換し, $\mathrm{B}$ 型血清中に $\mathrm{A}$ 酵素 活性が存在することを証明した。

糖ヌクレオチドの提供を受けた大阪赤十字血液セン ターの瀬尾たい子技官, 血液の提供を受けた熊谷赤十字 血液センターの村田 愿部長と伏見隆子技官他職員各 位, 群馬県赤十字血液センターの職員各位に謝意を表し ます。

\section{文献}

1) Race, R.R. and Sanger, R. : Blood Groups in Man. Sixth Edition., Blackwell Scientific Publications, Oxford and Edinburgh, 1975, pp. 8-18.

2) Hakomori, S.: Blood group $\mathrm{ABH}$ and Ii antigens of human erythrocytes: Chemistry, polymorphism, and their developmental change. Seminars in Hematology, 18:39-62, 1981.

3) Yoshida, A. : Biochemical genetics of human blood group ABO system. Am. J.
Hum. Genet., 34 : 1-14, 1982.

4) Kim, Y.S., Perdomo, J., Bella, A. and Nordberg, J.: $N$-acetyl-D-galactosaminyltransferase in human serum and erythrocyte membranes. Proc. Nat. Acad. Sci. USA, 68 : 1753-1756, 1971.

5) Sawicka, T.: Glycosyltransferases of human plasma. FEBS Letters, $16: 346-348$, 1971.

6) Schachter, H., Michaels, M.A., Crookston, M. C., Tilley, C.A. and Crookston, J.H, : A quantitative differences in the activity of blood grouup Aspecific $N$-acetylgalactosaminyltransferase in serum from $A_{1}$ and $A_{2}$ human subjects. Biochem. Biophys. Res. Commun., 45 : 1011-1018, 1971.

7) Whitehead, J.S., Bella, A., and Kim, Y.S. : An $N$-acetylgalactosaminyltransferase from human group A plasma. II. Kinetic and physicochemical properties. J. Biol. Chem., $249: 3448-3452,1974$.

8) Cartron, J.P., Badet, J., Mulet, C. and Salmon, C.: Study of the $\alpha-N$-acetylgalactosaminyltransferase in sera and red cell membranes of human A subgroups. 5 : 107-116, 1978.

9) Hearn, V.M., Smith, Z.G. and Watkins, W. M. : An $\alpha-N$-acetylgalactosaminyltransferase associated with the blood-group A character. Biochem. J., 109 : 315-317, 1968.

10) Tuppy, H. and Schenkel-Brunner, H. : Occurrence and assay of $\alpha-N$-acetylgalactosaminyltransferase in the gastric mucosa of humans belonging to blood group A. Vox Sang., $17:$ 139-142, 1969.

11) Ziderman, D., Gompertz, S., Smith, Z.G. and Watkins, W.M.: Glycosyltransferases in mammalian gastric mucosal linings. Biochem. Biophys. Res. Commun., 29:51-61, 1967.

12) Shenkel-Brunner, H. and Tuppy, H. : Enzymes from human gastric mucosa conferring blood-group $\mathrm{A}$ and $\mathrm{B}$ specificities upon erythrocytes. Eur. J. Biochem., 17 : 218-222, 
1970.

13）滝沢久夫： $\mathrm{A} お$ よび $\mathrm{B}$ 型物質の合成機序につ いて. 北関東医.，22：109-122, 1972.

14) Hearn, V.M., Race, C. and Watkins, W.M. : $\alpha-N$-acetylgalactosaminyl and $\alpha$-galactosyltransferases in human ovarian cyst epithelial linings and fluids. Biochem. Biophys. Res. Commun., 46 : 948-956, 1972.

15) Kobata, A. and Ginsburg, V.: Uridine diphosphate- $N$-acetyl-D-galactosamine : D- galactose $\quad \alpha-3-N$-acetylgalactosamnyltransferase, a product of the gene that determines blood type A in man. J. Biol. Chem., $245: 1484-1490,1970$.

16) Schachter, H., Michaels, M.A., Tilley, C,A. Crookston M.C. and Crookston, J.H. : Qualitative differences in the $N$-acetylgalactosaminyltransferases produced by human $A^{1}$ and $A^{2}$ genes. Proc. Nat. Acad. Sci. USA, $70: 220-224,1973$.

17) Topping, M.D. and Watkins, W.M. : Isoelectric points of the human blood group $A^{1}$, $A^{2}$ and $B$ gene associated glycosyltransferases in ovarian cyst fluids and serum. Biochem. Biophys. Res. Commun., 64 : 89-96, 1975.

18) Cartron, J.P., Gerbal, A., Badet, J., Ropars, C. and Salmon, C. : Assay of $\alpha-N$-acetylgalactosaminyltransferases in human sera. Vox Sang., $28: 347-365,1975$.

19）林成律, 文國鎮: Studies on phytohemagglutinin in Falcata japonica K., 高麗大 学校医科大学雑誌, $11: 397-407,1974$.

20）中島たみ子，古川 研，小暮正久：ヤブマメ (Falcata japonica) の抗A凝集素蔳する研究, 北関東医., $25: 439-446,1975$.

21）中島たみ子，古川 研：ヤブマメの抗 $\mathrm{A}$ 凝集 素の分離精製とその性状に関する研究，北関東 医., $28: 451-457,1978$.

22）西沢隆司：ヒトの血液型抗体の免疫グロブリ ンのクラスに関する研究 I 。自然抗体の免疫 グロブリンクラス。北関東医., $32: 423-437$, 1982.

23）西沢隆司：ヒトの血液型抗体の免疫グロブリ
ンのクラスに関する研究 II. 免疫抗体及びそ の他の不規則抗体の免疫グロブリンのクラス. 北関東医.，32：439-449, 1982.

24) Schenkel-Brunner. H. and Tuppy, H. : Enzymatic conversion of human blood -group-O erythrocytes into $A_{2}$ and $A_{1}$ cells by $\alpha-N$-acetyl-D-galactosaminyltransferases of blood-group-A individuals. Eur. J. Biochem., 34 : 125-128, 1973.

25) Watkins, W.M., Yates, A.D., Greenwell, P., Bird. G.W.G., Gibson, M., Roy, T.C.F., Wingham, J. and Loeb, W. : A human dispermic chimera first suspected from analyses of the blood group gene-specified glycosyltransferases. J. Immunogenetics, $8: 113$ $-128,1981$.

26) Greenbury, C.L., Moore, D.H. and Nunn, L. A.C. : Reaction of $7 \mathrm{~S}$ and 19S components of immune rabbit antisera with human group $\mathrm{A}$ and $\mathrm{AB}$ red cells. Immunology, $6: 421-433$, 1963.

27）小暮正久： $\mathrm{A}$ 分離酵素による $\mathrm{A}_{1}$ 抢よび $\mathrm{A}_{2}$ 型血球の $\mathrm{A}$ 型抗原決定群の研究. 日本輸血学雑 誌, $17: 75-81,1970$.

28) Cartron, J.P., Hughes-Jones, N.C. and Salmon, C. : 'Weak A' phenotypes relationship between red cell agglutinability and antigen site density. Immunology, $27:$ 723-727, 1974.

29) Furukawa, K., Takizawa, H. and Iseki, S. : Serological activity of red cells and saliva of blood groups $A_{1}$ and $A_{2}$. Jap. J. Hum. Genet., 19: 183-190, 1974.

30) Yoshida, A., Davé, V., Branch, D.R., Yamaguchi, $\mathrm{H}$. and Okubo, Y. : An enzyme basis for blood type A intermadiate status. Am. J. Hum. Genet., 34 : 919-924, 1982.

31) Nagai, M. and Yoshida, A. : Possible existence of hybrid glycosyltransferase in heterozygous blood group AB subjects. Vox Sang., $35: 378-381,1978$.

32) Yoshida, A.: The existence of atypical blood group galactosyltransferase which causes an expression of $\mathrm{A}_{2}$ character in $A^{1} B$ red blood cells. Am. J. Hum. Genet., $35: 1117$ 
$-1125,1983$.

33) Watkins, W.M., Greenwell, P. and Yates, A. D. : The genetic and enzymatic regulation of the synthesis of the $\mathrm{A}$ and $\mathrm{B}$ determinants in the $\mathrm{ABO}$ blood group system. Immunol. Commun., $10: 83-100,1981$.

34) Yates, A.D. and Watkins, W.M. : The biosynthesis of blood group B determinants by the blood group $A$ gene-specified $\alpha-3-N-$ acetyl-D- glactosaminyltransferase. Biochem. Biophys. Res. Commun., 109 : 958-965, 1982.

35) Nagai, M., Davé, V., Kaplan, B.E. and Yoshida, A. : Human blood group glycosyltransferases I. Purification of $N$-acetylgalactosaminyltransferase. J. Biol. Chem., $253: 377$
$-379,1978$.

36) Nakajima, T., Takayanagi, R., Yazawa, S., Kogure, T., Furukawa, K., Seno, T. and Yamaguchi, H. : A family example of $A_{\text {int }}$ which demonstrate different $A$ antigen strength and activity of A-enzyme. Jap. J. Human Genet., $28: 118,1983$.

37) Kościelak, J., Pacuszka, T. and Dzierźkowa -Borodej, W. : Activity of B-gene-specified galactosyltransferase in individuals with $B_{m}$ phenotypes. Vox Sang., $30: 58-67,1976$.

38) Kogure, T.: The action of group $B_{m}$ or cis $\mathrm{AB}$ sera on group $\mathrm{O}$ red cells in the presence of UDP-D-galactose. Vox Sang., $29: 51-58$, 1975.

\title{
STUDIES ON AGGLUTINABILITY OF ERYTHROCYTES AND ACTIVITY OF $\alpha$-N-ACETYL-D-GALACTOSAMINYLTRANSFERASES IN SERA FROM HUMAN A SUBGROUPS
}

\section{TAMIKO NAKAJIMA}

\author{
Department of Legal Medicine, Gunma University \\ School of Medicine, Maebashi, Japan \\ (Director: Prof. Ken Furukawa)
}

Standard procedure for determination of A subgroups was established by agglutinability of red cells using Falcata japonica lectin besides the reaction with human anti-A, eel anti-H sera and Dolichos biflorus lectin. Family example of $\mathrm{A}_{\mathrm{int}}$ which members demonstrate difference in $\mathrm{A}$ antigen strength of erythrocytes and in activity of serum A-enzyme was found by the standarized procedure. $\mathrm{A}_{2}$ and $\mathrm{A}_{3}$ red cells did not react with Dolichos biflorus while Falcata japonica agglutinated $\mathrm{A}_{2}$ red cells but not $\mathrm{A}_{3}$ red cells at a titier of $1: 64$. There are dispersions in agglutinability of $A_{2}$ red cells with Falcata japonica. Weaker $\alpha$-N-acetylgalactosaminyltransferase activity than that of $\mathrm{A}_{1}$ was demonstrated in $A_{\text {int }}$ and $A_{2}$ sera by the conversion of group $O$ red cells into $A$ active cells using papain treated cells as acceptor and anti-A immune serum for agglutinability test. A-transferase activity which converts $\mathrm{O}$ red cells into A active cells at the presence of UDP- $N$-acetylgalactosamine was found in group B sera.

Key words: Blood groups, Erythrocytes, Lectin, $N$-acetylgalactosaminyltransferase, Galactosyltransferase. 